\title{
Penerapan Metode Tanya Jawab Dalam Meningkatkan Kemampuan Identifikasi Jenis Gerak Makhluk Hidup
}

\author{
YUSNIARTI \\ Dinas Pendidikan Kabupaten Kampar \\ SMP Negeri 4 Siak Hulu \\ E-mail : yusniarty@yahoo.com
}

\begin{abstract}
A teacher realizes that the central point of the school's goal is to provide an educational program planned to meet the needs of things related to education, personal and community needs and the individual interests of students. Students are the main clients that must be served, therefore students must be actively and precisely involved, not only in the teaching and learning process but also in school activities. In Siak Hulu 4 Public Middle School, based on observations in the field of learning the types of motion of living things found the phenomenon of achieving student learning outcomes less than KKM or said to have not succeeded. The application of the question and answer method is thought to improve students' ability to identify the type of motion. Through class action research methods and surveyed to class VIII students and analyzed with descriptive analysis techniques, the results show the acquisition of learning outcomes through question and answer Cycles I, II and III completeness of individuals only reached $42.5,52.5$ and 77.5 Portrait of science learning has reached the goal with standards KKM 71. There is an increase in learning outcomes of IPS matergers in living things by applying the question and answer method so that learning outcomes have increased.
\end{abstract}

Keywords: Question and Answer Method, Identify Motion Types

Setiap makhluk hidup (organisme) mampu menerima dan menanggapi rangsangan yang disebut iritabilitas. Salah satu bentuk tanggapan yang umum dilakukan berupa gerak. Gerak adalah perubahan posisi tubuh atau perpindahan yang meliputi seluruh atau sebagian dari tubuh sebagai respon yang diberikan terhadap rangsangan dari lingkungan dan akibat adanya pertumbuhan. Gerak merupakan salah satu ciri makhluk hidup yang bertujuan untuk melaksanakan kegiatan hidupnya. Gerak yang terjadi pada tumbuhan berbeda dengan gerak yang dilakukan oleh hewan dan manusia. Gerak pada tumbuhan bersifat pasif, artinya tidak memerlukan adanya pindah tempat. Gerak dapat terjadi karena adanya pengaruh rangsangan (stimulus).

Rangsangan yang mempengaruhi terjadinya suatu gerak pada tumbuhan antara lain : cahaya, air, sentuhan, suhu, gravitasi dan zat kimia. Rangsangan tersebut ada yang menentukan arah gerak tumbuhan dan ada pula yang tidak menentukan arah gerak tumbuhan.
Rangsangan yang menentukan arah gerak akan menyebabkan tumbuhan bergerak menuju atau menjauhi sumber rangsangan.

Iritabilitas pada tumbuhan disebabkan karena adanya bagian dinding sel yang tidak mengalami penebalan. Pada bagian ini terdapat suatu celah yang disebut noktah yang menghubungkan sel satu dengan yang lain. Melalui noktah terjadi hubungan antara sel satu dengan lainnya oleh penjuluran-penjuluran protoplasma atau benang-benang plasma yang disebut plasmodesmata.

Seorang guru menyadari bahwa titik pusat tujuan sekolah menyediakan program pendidikan yang direncanakan untuk memenuhi kebutuhan hal-hal yang berkaitan dengan pendidikan, pribadi dan kebutuhan kemasyarakatan serta kepentingan individu para siswa. Siswa merupakan klien utama yang harus dilayani, oleh sebab itu siswa harus dilibatkan secara aktif dan tepat, tidak hanya dalam proses belajar mengajar 
melainkan juga di dalam kegiatan sekolah.

Perubahan yang makin meningkat mengakui bahwa guru secara individual harus mendapatkan perhatian. Terdapat banyak hal yang perlu mendapatkan perhatian dari seorang guru, seperti masalah kompetensinya. Berbicara masalah kompetensi guru saat ini menjadi hal yang menarik. Banyak persoalan tentang kompetensiguru dalam memberikan pelayanan pendidikan kepada peserta didik, seperti persoalan dunia kerja guru yang memberikan pengajaran, guru dengan pimpinannya, kemudian persoalan guru dengan muridnya, guru dengan lingkungannya juga menjadi masalah tersendiri yang ikut menentukan mutu pendidikan.

Lokasi penelitian ini dilakukan di SMP Negeri 4 Siak Hulu, berdasarkan pengamatan di lapangan pada pelajaran IPA ditemukan fenomena pencapaian hasil belajar siswa kurang dari KKM atau dikatakan belum berhasil. Diketahui bahwa berdasarkan pre tes yang dilakukan pada mata pelajaran IPA khususnya mengenai gerak pada makhluk hidupdari 40 siswa terdapat $57 \%$ siswanya yang tidak tuntas atau lebih kecil hasil belajarnya dibandingkan dengan KKM yang ditetapkan yakni 71 .

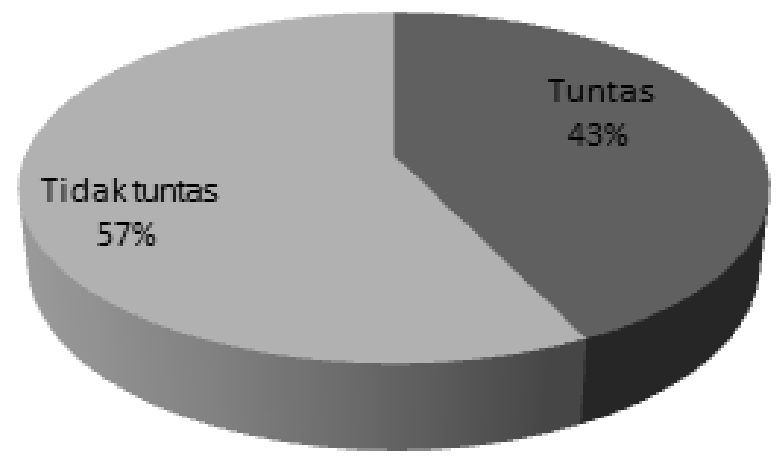

Gambar 1: Ketuntasan Belajar Siswa

Kemudian sikap siswa dalam belajar cenderung pasif dalam mengikuti pelajaran, dimana pada saat guru meminta siswa bertanya atau menanggapi pelajaran yang diberikan siswa cenderung diam saja dan juga pada saat guru bertanya kepada siswa, siswa malahan ketakutan menjawabnya. Selain itu juga siswa kurang semangat mengikuti materi pelajaran yang diberikan dan berusaha untuk mencari alasan untuk tidak mengikutinya.

Hasil penelitian sebelumnya menjelaskan bahwa dalam membelajarkan ilmu pengetahuan alam kepada siswa, apabila guru masih menggunakan paradigma pembelajaran lama dalam arti komunikasi dalam pembelajaran ilmu pengetahuan social Pembelajaran kooperatif adalah strategi belajar dimana siswa belajar dalam kelompok kecil yang memiliki tingkat kemampuan yang berbeda. Pembelajaran dengan pendekatan keterampilan proses dalam seting pembelajaran kooperatif tipe STAD dapat mengubah pembelajaran dari teacher center menjadi student centered. Zulhartati, S. (2012).

Berdasarkan uraian pada latar belakang masalah tersebut di atas, maka penulis tertarik membuktikannya dalam sebuah penelitian perumusan masalah dalam penelitian ini adalah apakah penerapan metode tanya jawab dapatmeningkatkan hasil belajar gerak pada makhluk hidup pada pelajaran IPA kelas VIII SMP Negeri 4 Siak Hulu.

Untuk menghindari salah pengertian atau salah tafsir tentang makna istilah yang digunakan dalam penelitian ini, maka perlu dijelaskan makna beberapa definisi operasional sebagai berikut : Metode tanya jawab merupakan sebuah kelompok model pembelajaran yang melibatkan siswa bekerja secara berkolaborasi untuk mencapai tujuan bersama. Gerak merupakan salah satu ciri makhluk hidup yang bertujuan untuk melaksanakan kegiatan hidupnya. Gerak yang terjadi pada tumbuhan berbeda dengan gerak yang dilakukan oleh hewan dan manusia. Gerak pada tumbuhan bersifat pasif, artinya tidak memerlukan adanya pindah tempat. Gerak dapat terjadi karena adanya pengaruh rangsangan (stimulus). 
Berdasarkan atas penyebab timbulnya gerak, dapat dibedakan antara gerak tumbuh dan gerak turgor. Berdasarkan arah rangsangannya, gerak pada tumbuhan dibedakan menjadi dua, yaitu : gerak etionom dan gerak endonom (autonom). Berdasarkan hubungan antara arah respon gerakan dengan asal rangsangan, gerak etionom dapat dibedakan menjadi : gerak tropisme, gerak nasti dan gerak taksis.

Tropisme adalah gerak bagian tumbuhan yang arah geraknya dipengaruhi oleh arah datangnya rangsangan. Mcammacam gerak tropisme adalah : fototropisme, geotropisme, hidrotropisme, kemotropisme, tigmotropisme dan gravitoprisme. Gerak nasti adalah gerak tumbuhan yang arahnya tidak dipengaruhi oleh arah datangnya rangsangan, tetapi ditentukan oleh tumbuhan itu sendiri, misalnya karena perubahan tekanan turgor. Macam-macam gerak nasti adalah : fotonasti, niktinasti, termonasti, tigmonasti, haptonasti dan nasti kompleks.

Taksis adalah gerak seluruh tubuh atau bagian dari tubuh tumbuhan yang berpindah tempat dan arah perpindahannya dipengaruhi rangsangan. Macam-macam gerak taksis adalah : fototaksis dan kemotaksis.

\section{Menurut Koswara}

(2008)

menyatakan bahwa kompetensi guru dapat dimaknai sebagai gambaran tentang apa yang seyogyanya dapat dilakukan seseorang guru dalam melaksanakan pekerjaannya, baik berupa kegiatan, berperilaku maupun hasil yang dapat ditunjukkan.

Inti dari pendidikan adalah interaksi antara guru dengan siswa dalam mencapai tujuan-tujuan pendidikan.Guru, siswa dan tujuan pendidikan adalah komponenkomponen pendidikan yang utama (esencial). Menurut Syaiful Sagala (2009) kompetensi guru adalah seperangkat pengetahuan, ketrampilan dan perilaku yang harus dimiliki, dihayati dan dikuasai oleh guru dalam melaksanakan tugas keprofesionalan.
Kemudian menurut Arni Muhammad dan Ilyas (2002: 49) ketiga komponen pendidikan ini membentuk suatu segitiga, yang jika hilang salah satu komponennya, maka akan hilanglah hakekat dari pendidikan. Sebagai seorang pendidik, tugas guru pada dasarnya adalah mendidik, yaitu membantu anak didik mengembangkan pribadinya, memperluas pengetahuannya, dan melatih keterampilannya dalam berbagai bidang.Untuk dapat melaksanakan tugas tersebut seorang guru harus memiliki sejumlah kemampuan, yang sering disebut dengan kompetensi profesional.

Usman (2002) memberikan pengertian kompetensi guru dengan kemampuan dalam melaksanakan kewajiban-kewajiban secara bertanggung jawab dan layak. Dari sisi lain berkaitan dengan kompetensi Prayitno (2002) mengatakan bahwa: Kompetensi merupakan pengetahuan, keterampilan, nilai, sikap dasar yang direfleksikan dalam kebiasaan berpikir dan bertindak yang bersifat dinamis, berkembang, dan dapat diraih setiap waktu. Kebiasaan berpikir dan bertindak secara konsisten dan terus menerus memungkinkan seseorang menjadi kompeten, dalam arti memiliki pengetahuan, keterampilan, nilai, dan sikap sikap dasar dalam melakukan sesuatu.

Dari pendapat para ahli di atas dapat disimpulkan bahwa kompetensi adalah karakteristik kemampuan individu yang dimiliki untuk melakukan dan memutuskan sesuatu kegiatan tertentu.Kemampuan tersebut terlihat dalam kegiatan berfikir dan bertindak yang dilakukan secara konsisten.

Proses belajar dan hasil belajar para siswa bukan saja ditentukan oleh sekolah, pola, stuktur, dan isi kurikulumnya, akan tetapi sebahagian besar ditentukan oleh kompetensi guru yang mengajar dan membimbing mereka. Guru yang kompeten akan lebih mampu menciptakan lingkungan belajar yang efektif, menyenangkan, dan akan mampu 
mengelola kelasnya, sehingga belajar siswa pada tingkat optimal. Berdasarkan pertimbangan dan analisis di atas, dapat diperoleh gambaran secara fundamental tentang pentingnya kompetensi guru.

Oemar Hamalik

menyebutkan kompetensi guru dalam jenjang pendidikan apapun meliputi kompetensi profesional, kompetensi kepribadian, dan kompetensi kemasyarakatan. Secara teoretis ketiga kompetensi ini dapat dipisah-pisahkan satu dengan yang lain, akan tetapi secara praktis sesungguhnya ketiga jenis kompetensi ini tidak dapat dipisah-pisahkan. Ketiga kompetensi ini saling menjalin secara terpadu dalam diri guru.Guru yang terampil mengajar tentu harus memiliki pribadi yang baik dan mampu melakukan social adjustment dalam masyarakat, ketiga kompetensi ini terpadu dalam karakteristik tingkah laku guru.

Menurut Imron (2003) bahwa pakar pendidikan seringkali menegaskan bahwa guru merupakan sumberdaya manusia yang sangat menentukan keberhasilan program pendidikan.Apapun yang telah dilakukan untuk meningkatkan mutu pendidikan yang pasti peningkatan mutu pendidikan tidak mungkin ada tanpa kualitas performa gurunya.Oleh karena itu peningkatan performa guru mutlak harus dilakukan secara terus menerus dalam rangka meningkatkan mutu pendidikan di sekolah.

Slameto (1991) menyebutkan bahwa: "mengajar adalah kegiatan mengorganisasi yang bertujuan untuk membantu dan menggairahkan siswa belajar". Mengajar dapat diartikan sebagai proses menyampaikan pengetahuan dan kecakapan tertentu kepada anak didik. Yang lain menyebutkan bahwa mengajar adalah mengorganisasi lingkungan secara kondusif sehingga dapat menciptakan kondusif kepada siswa untuk melakukan proses belajar secara efektif.

Mengajar merupakan aktifitas yang dilakukan oleh guru dalam melakukan interaksi dengan siswa. Aktivitas guru dilakukan secara bertahap, diawali dengan menyusun

perencanaan

secara menyeluruh tentang segala sesuatu yang akan dilakukan pada saat terjadi interaksi dengan siswa dan pemanfaatan sumbersumber yang ada untuk mendukung selama kegiatan yaitu melakukan evaluasi, menganalisis dan melakukan pencatatan-pencatratan terhadap sesuatu yang terjadi pada saat interaksi berlangsung.

Pada saat terjadi interaksi dengan siswa, maka guru memilih dan melakukan dengan cara-cara tertentu agar kegiatan interaksi dengan siswa dapat berjalan dengan kondusif sehingga tujuan yang diharapkan dapat tercapai.Cara-cara yang dilakukan oleh guru dalam melakukan interaksi dengan siswa disebut metode mengajar.

Metode mengajar memiliki peranan yang sangat penting dalam proses belajar mengajar. Soetomo (1993) menyebutkan: "metode mengajar sebagai suatu alat untuk mencapai tujuan pengajaran yang ingin dicapai, sehingga semakin baik penggunaan metode mengajar semakin berhasillah pencapaian tujuan. Penggunaan metode mengajar secara tepat dapat menumbuhkan minat siswa untuk dapat mengikuti kegaitan belajar mengajar dengan baik, sehingga kreatifitas anak akan muncul dan berkembang dengan baik pula. Namun sebaliknya, jika penggunaan metode mengajar ini kurang tepat, maka akan menjadi tidak bermakna bahkan dapat mematikan kreatifitas siswa.

Penelitian metode mengajar sangat tergantung pada sutuasi dan kondisi yang saat guru mengajar.Tidak semua metode mengajar selalu tepat digunakan untuk menyampaikan materi pelajaran. Metode mengajar sangat banyak ragamnya, antara lain: metode ceramah, metode Tanya jawab, metode tanya jawab, metode pemberian tugas, metode bermain peran, metode inkuiri, metode demonstrasi, metode pemecahan masalah. Berbagai metode tersebut memiliki kelebihan dan kekurangannya masing-masing. Juga hal 
ini disampaikan oleh Hadiyati (2017) bahwa metode pembelajaran menjadi cara untuk mencapai keberhasilan belajar.

\section{METODE}

Prosedur penelitian tindakan kelas yakni: 1) perencanaan (planning), 2) tindakan (acting), 3) pengamatan (observing), dan 4) refleksi (reflecting). Siswa kelas VIII sebanyak 40 orang di SMP N 4 Siak Hulu sebagai sampel penelitian. Data dikumpulkan dengan menggunakan kuesioner dan analisis data dalam penelitian tindakan kelas ini menggunakan analisis kuantitatif dan kualitatif (Supardi, 2006:131). Terhadap perolehan hasil belajar IPA dianalisis secara kuantitatif dengan memberikan nilai pada hasil belajar siswa. Data-data tersebut dianalisis mulai dari siklus satu sampai dengan siklus juga untuk dibandingkan dengan teknik deskriptif presentase.Hasil perhitungan dikonsultasikan dengan tabel kriteria deskriptif prosentase, yang dikelompokkan dalam 3 kategori, yaitu baik, cukup, kurang. Hasil observasi dianalisis menggunakan teknik deskriptif kualitatif yang digambarkan dengan kata-kata atau kalimat, dipisah-pisahkan menurut kategori untuk memperoleh kesimpulan.

\section{HASIL}

Telah diketahui bahwa subjek penelitian berjumlah 40 siswa. Pelaksanaan penelitian tindakan kelas ini dilakukan dalam 3 (tiga) siklus, yakni siklus I. Berikut disajikan paparan hasil penelitian yang terdiri atas hasil belajar IPS melalui kolaborasi model pembelajaran tanya jawab dan hasil observasi terhadap proses pembelajaran.

\section{Siklus I}

Berdasarkan data hasil penelitian siklus I mengenai hasil belajar IPA materi pokokhukum I Gerak pada makhluk hidupsecara sederhana dan penerapannya dalam kehidupan sehari-hari, melalui model pembelajaran tanya jawab ,sebagai berikut:
Tabel 1 : Hasil Belajar Siklus I (75)

\begin{tabular}{|c|c|c|c|}
\hline No & Nama & Nilai & Keterangan \\
\hline 1 & Aldi Rahman & 59 & Tidak Tuntas \\
\hline 2 & Aldo Pratama & 59 & Tidak Tuntas \\
\hline 3 & Anggi Pratiwi & 84 & Tuntas \\
\hline 4 & Arya Rizki & 54 & Tidak Tuntas \\
\hline 5 & Cristin Elisabeth & 69 & Tidak Tuntas \\
\hline 6 & Dheaerysia Eyra & 49 & Tidak Tuntas \\
\hline 7 & Diki Rahmad Imandani & 89 & Tuntas \\
\hline 8 & Dini Swara & 59 & Tidak Tuntas \\
\hline 9 & Elni Saputra & 49 & Tidak Tuntas \\
\hline 10 & Erlinda Nurhayati & 69 & Tidak Tuntas \\
\hline 11 & Ester Diba R.S & 74 & Tuntas \\
\hline 12 & Fauzan Hamzah & 54 & Tidak Tuntas \\
\hline 13 & Fauzi Wahyudi & 89 & Tuntas \\
\hline 14 & Imanuel Hutabarat & 49 & Tidak Tuntas \\
\hline 15 & Jhodi Mahendra & 89 & Tuntas \\
\hline 16 & Khairul Zoni & 59 & Tidak Tuntas \\
\hline 17 & Khoirul Bazar & 89 & Tuntas \\
\hline 18 & Marco Andreas & 59 & Tidak Tuntas \\
\hline 19 & Mardia Roza Utami & 89 & Tuntas \\
\hline 20 & Maulana Safaat & 59 & Tidak Tuntas \\
\hline 21 & Mikha Putri Sihotang & 54 & Tidak Tuntas \\
\hline 22 & M. Hidayat Panca & 59 & Tidak Tuntas \\
\hline 23 & M. Syafrizal & 59 & Tidak Tuntas \\
\hline 24 & Mutiara Indah Sari & 89 & Tuntas \\
\hline 25 & Nerli Lupita & 74 & Tuntas \\
\hline 26 & Novi Ramadhani & 59 & Tidak Tuntas \\
\hline 27 & Olivia Ardechi & 74 & Tuntas \\
\hline 28 & Pasty Cristina & 89 & Tuntas \\
\hline 29 & Rachel Saragih & 84 & Tuntas \\
\hline 30 & Raffil Ferera & 84 & Tuntas \\
\hline 31 & Rangga Sumantri & 54 & Tidak Tuntas \\
\hline 32 & Rina Lestari S & 69 & Tidak Tuntas \\
\hline 33 & Rina Yanti P & 89 & Tuntas \\
\hline 34 & Sabrina Khairunnisa & 84 & Tuntas \\
\hline 35 & Selviana Sari & 54 & Tidak Tuntas \\
\hline 36 & Suci Asih Ramadhani & 69 & Tidak Tuntas \\
\hline 37 & Syahrul Ar Rasyid & 59 & Tidak Tuntas \\
\hline 38 & Wenni Sasmita & 84 & Tuntas \\
\hline 39 & Witra Muhammad & 44 & Tidak Tuntas \\
\hline 40 & Yohannes Marksya & 84 & Tuntas \\
\hline
\end{tabular}




\begin{tabular}{|l|l|c|l|}
\hline No & Nama & Nilai & Keterangan \\
\hline & Rata-Rata & 69 & Tidak Tuntas \\
\hline & Tuntas & 17 & $42.5 \%$ \\
\hline & Tidak tuntas & 23 & $57.5 \%$ \\
\hline & & 40 & $100.0 \%$ \\
\hline
\end{tabular}

Berdasarkan data tersebut diperoleh informasi untuk pada ketuntasan 71 sebanyak $42,5 \%$ tuntas dan rata-rata hasil belajar sebesar 69. Sedangkan sisanya 57,5\% tidak tuntas. Dari tabel diatas menunjukkan bahwa perolehan hasil belajar melalui tanya jawab Siklus I ketuntasan individual baru mencapai 42,5\%. Potret pembelajaran IPA belum mencapai tujuan yang diharapkan guru yang tertuang dalam indikator kinerja $>85 \%$ dari jumlah siswa dalam kelas telah mencapai ketuntasan belajar individual, sehingga perlu dilaksanakan siklus II.

\section{Siklus II}

Berdasarkan data hasil penelitian siklus I mengenai hasil belajar IPA materi pokok mendemonstarsikan hukum II Gerak pada makhluk hidupdan penerapannya dalam kehidupan sehari-hari, melalui model pembelajaran tanya jawab sebagai berikut:

Tabel 2 : Hasil Belajar Siklus II

\begin{tabular}{|l|l|l|l|}
\hline No & Nama & Nilai & Keterangan \\
\hline 1 & Aldi Rahman & 65 & Tidak Tuntas \\
\hline 2 & Aldo Pratama & 65 & Tidak Tuntas \\
\hline 3 & Anggi Pratiwi & 90 & Tuntas \\
\hline 4 & Arya Rizki & 60 & Tidak Tuntas \\
\hline 5 & Cristin Elisabeth & 75 & Tuntas \\
\hline 6 & Dheaerysia Eyra & 55 & Tidak Tuntas \\
\hline 7 & Diki Rahmad Imandani & 95 & Tuntas \\
\hline 8 & Dini Swara & 65 & Tidak Tuntas \\
\hline 9 & Elni Saputra & 55 & Tidak Tuntas \\
\hline 10 & Erlinda Nurhayati & 75 & Tuntas \\
\hline 11 & Ester Diba R.S & 80 & Tuntas \\
\hline 12 & Fauzan Hamzah & 60 & Tidak Tuntas \\
\hline 13 & Fauzi Wahyudi & 95 & Tuntas \\
\hline 14 & Imanuel Hutabarat & 55 & Tidak Tuntas \\
\hline 15 & Jhodi Mahendra & 95 & Tuntas \\
\hline 16 & Khairul Zoni & 65 & Tidak Tuntas \\
\hline 17 & Khoirul Bazar & 95 & Tuntas \\
\hline
\end{tabular}

Diklat Review: Jurnal Manajemen Pendidikan dan Pelatihan

\begin{tabular}{|c|c|c|c|}
\hline No & Nama & Nilai & Keterangan \\
\hline 18 & Marco Andreas & 65 & Tidak Tuntas \\
\hline 19 & Mardia Roza Utami & 95 & Tuntas \\
\hline 20 & Maulana Safaat & 65 & Tidak Tuntas \\
\hline 21 & Mikha Putri Sihotang & 60 & Tidak Tuntas \\
\hline 22 & M. Hidayat Panca & 65 & Tidak Tuntas \\
\hline 23 & M. Syafrizal & 65 & Tidak Tuntas \\
\hline 24 & Mutiara Indah Sari & 95 & Tuntas \\
\hline 25 & Nerli Lupita & 80 & Tuntas \\
\hline 26 & Novi Ramadhani & 65 & Tidak Tuntas \\
\hline 27 & Olivia Ardechi & 80 & Tuntas \\
\hline 28 & Pasty Cristina & 95 & Tuntas \\
\hline 29 & Rachel Saragih & 90 & Tuntas \\
\hline 30 & Raffil Ferera & 90 & Tuntas \\
\hline 31 & Rangga Sumantri & 60 & Tidak Tuntas \\
\hline 32 & Rina Lestari S & 75 & Tuntas \\
\hline 33 & Rina Yanti P & 95 & Tuntas \\
\hline 34 & Sabrina Khairunnisa & 90 & Tuntas \\
\hline 35 & Selviana Sari & 60 & Tidak Tuntas \\
\hline 36 & Suci Asih Ramadhani & 75 & Tuntas \\
\hline 37 & Syahrul Ar Rasyid & 65 & Tidak Tuntas \\
\hline 38 & Wenni Sasmita & 90 & Tuntas \\
\hline 39 & Witra Muhammad & 50 & Tidak Tuntas \\
\hline 40 & Yohannes Marksya & 90 & Tuntas \\
\hline & Rata-Rata & 75 & Tuntas \\
\hline & Tuntas & 21 & $52.5 \%$ \\
\hline & Tidak tuntas & 19 & $47.5 \%$ \\
\hline & & 40 & $100.0 \%$ \\
\hline
\end{tabular}

Dari tabel 2 di atas menunjukkan bahwa perolehan hasil belajar melalui tanya jawab Siklus II ketuntasan individual $52.5 \%$. Potret pembelajaran IPA sudah mencapai tujuan yang diharapkan guru yang tertuang dalam indikator kinerja > 85\% dari jumlah siswa dalam kelas telah mencapai ketuntasan belajar individual, sehingga untuk kesempurnaan perlu dilaksanakan siklus III.

\section{Siklus III}

Berdasarkan data hasil penelitian siklus I mengenai hasil belajar IPA materi pokok mendemonstarsikan hukum II Gerak pada makhluk hidupdan penerapannya 
dalam kehidupan sehari-hari, melalui model pembelajaran tanya jawab diperoleh data untuk ketuntasan 71 sebagai berikut:

Tabel 3 : Hasil Belajar Siklus III

\begin{tabular}{|c|c|c|c|}
\hline No & Nama & Nilai & Keterangan \\
\hline 1 & Aldi Rahman & 71 & Tuntas \\
\hline 2 & Aldo Pratama & 71 & Tuntas \\
\hline 3 & Anggi Pratiwi & 95 & Tuntas \\
\hline 4 & Arya Rizki & 65 & Tidak Tuntas \\
\hline 5 & Cristin Elisabeth & 80 & Tuntas \\
\hline 6 & Dheaerysia Eyra & 60 & Tidak Tuntas \\
\hline 7 & Diki Rahmad Imandani & 100 & Tuntas \\
\hline 8 & Dini Swara & 71 & Tuntas \\
\hline 9 & Elni Saputra & 60 & Tidak Tuntas \\
\hline 10 & Erlinda Nurhayati & 80 & Tuntas \\
\hline 11 & Ester Diba R.S & 85 & Tuntas \\
\hline 12 & Fauzan Hamzah & 71 & Tuntas \\
\hline 13 & Fauzi Wahyudi & 100 & Tuntas \\
\hline 14 & Imanuel Hutabarat & 60 & Tidak Tuntas \\
\hline 15 & Jhodi Mahendra & 100 & Tuntas \\
\hline 16 & Khairul Zoni & 71 & Tuntas \\
\hline 17 & Khoirul Bazar & 100 & Tuntas \\
\hline 18 & Marco Andreas & 71 & Tuntas \\
\hline 19 & Mardia Roza Utami & 100 & Tuntas \\
\hline 20 & Maulana Safaat & 71 & Tuntas \\
\hline 21 & Mikha Putri Sihotang & 65 & Tidak Tuntas \\
\hline 22 & M. Hidayat Panca & 71 & Tuntas \\
\hline 23 & M. Syafrizal & 71 & Tuntas \\
\hline 24 & Mutiara Indah Sari & 100 & Tuntas \\
\hline 25 & Nerli Lupita & 85 & Tuntas \\
\hline 26 & Novi Ramadhani & 71 & Tuntas \\
\hline 27 & Olivia Ardechi & 85 & Tuntas \\
\hline 28 & Pasty Cristina & 100 & Tuntas \\
\hline 29 & Rachel Saragih & 95 & Tuntas \\
\hline 30 & Raffil Ferera & 95 & Tuntas \\
\hline 31 & Rangga Sumantri & 65 & Tidak Tuntas \\
\hline 32 & Rina Lestari S & 80 & Tuntas \\
\hline 33 & Rina Yanti P & 100 & Tuntas \\
\hline 34 & Sabrina Khairunnisa & 95 & Tuntas \\
\hline 35 & Selviana Sari & 65 & Tidak Tuntas \\
\hline 36 & Suci Asih Ramadhani & 80 & Tuntas \\
\hline 37 & Syahrul Ar Rasyid & 70 & Tidak Tuntas \\
\hline 38 & Wenni Sasmita & 95 & Tuntas \\
\hline
\end{tabular}

\begin{tabular}{|l|l|l|l|}
\hline No & Nama & Nilai & Keterangan \\
\hline 39 & Witra Muhammad & 55 & Tidak Tuntas \\
\hline 40 & Yohannes Marksya & 95 & Tuntas \\
\hline & Rata-Rata & 81 & Tuntas \\
\hline & Tuntas & 31 & $77.5 \%$ \\
\hline & Tidak tuntas & 9 & $22.5 \%$ \\
\hline & & 40 & $100.0 \%$ \\
\hline
\end{tabular}

Dari tabel 3 di atas menunjukkan bahwa perolehan hasil belajar melalui tanya jawab Siklus III ketuntasan individual mencapai $77.5 \%$. Potret pembelajaran IPA sudah mencapai tujuan yang diharapkan guru telah mencapai.

\section{PEMBAHASAN}

Hasil observassi pada siklus III diperoleh gambaran tentang sikap disiplin (discipline) dalam belajar dengan menghargai waktu belajar dan juga petunjuk belajar yang diberikan sudah baik, kemudian memiliki rasa hormat kepada guru dan sesama rekan belajar dalam bertanya jawab dan perhatian (respect) terhadap berbagai pertanyaan dan perubahan yang terjadi dengan mengkritisinya sudah baik serta tekun (diligence) dalam menyelesaikan tugas yang diberikan guru di kelas baik, tanggung jawab (responsibility) terhadap tugas yang diberikan dalam bentuk menyelesaikan tugas dan ketelitian (carefulness) dalam menyelesaikan tugas sesuai dengan fakta materi yang diberikan juga baik.

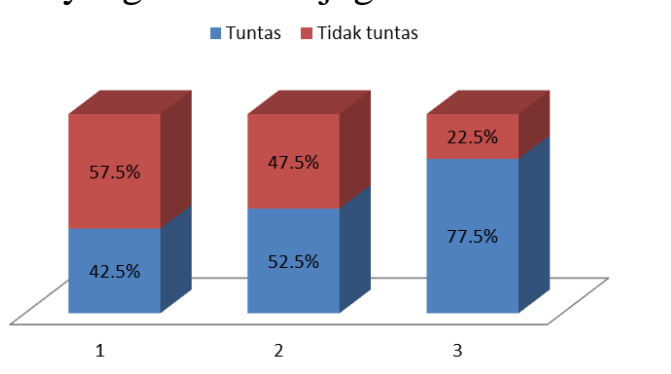

Gambar 2: Ketuntasan 3 Siklus

Dari sudut guru kemampuan mengajar guru sudah baik, ada peningkatan yang signifikan. Guru sudahbaik dalam mengelola ruang, fasilitas, strategi, interaksi dengan siswa, dan evaluasi dengan baik juga untuk pengelolaan waktu sudah dapat 
terlaksana dengan efektif, karena guru sudah terbiasa menggunakan model pembelajaran. Kesan umum guru dalam mengajar sudah luwes dan sudah peka dengan kondisi siswa.

\section{SIMPULAN}

Berdasarkan hasil penelitan yang telah dilaksanakan, maka dapat ditarik beberapa kesimpulan sebagai berikut: Perolehan hasil belajar melalui tanya jawab Siklus I, II dan III ketuntasan individual baru mencapai 42.5, 52.5 dan 77.5 Potret pembelajaran IPA sudah mencapai tujuan dengan standar KKM 71. Terdapat peningkatan hasil belajar IPA materigerak pada makhluk hidup dengan menerapkan metode tanya jawab sehingga hasil belajar mengalami peningkatan.

Berdasarkan simpulan diatas, maka penulis mengajukan saran sebagai berikut: Para guru, hendaknya bisa merubah RPP dari metode lama yakni belajar dengan menggunakan metode ceramah menjadi belajar dengan menggunakan metode tanya jawab. Kepala Sekolah diharapkan dapat menggunakan informasi hasil penelitian ini dalam rangka pengambilan keputusan berkaitan dengan peningkatan hasil belajar siswa dan pada gilirannya akan meningkatkan kualitas pendidikan sekolah.

\section{DAFTAR RUJUKAN}

Arni, Muhammad, 2005, Komunikasi Organisasi, Jakarta : Bumi Aksara.

Hadiyati, H., Fatkhurahman, F., \& Suroto, B. (2017). Pelatihan Manajemen Penulisan Karya Tulis Ilmiah Bagi Tenaga Pendidik Di SMP N 3 Kampar Kiri Tengah. Dinamisia: Jurnal Pengabdian Kepada Masyarakat, 1(1, Des), 122-128.

Imron, Ali,. Maisyaroh,. Burhanuddin, 2003, Manajemen Pendidikan. Analisis Substantif dan Aplikasinya dalam Institusi Pendidikan, Universitas Negeri Malang, Malang.
Koswara, Deni dan Halimah, 2008, Bagaimana Menjadi Guru Kreatif?, Pribumi Mekar, Bandung.

Oemar Hamalik, 2002, Pendidikan Guru: Berdasarkan Pendekatan Kompetensi. Jakarta: Bumi Aksara.

Prayitno. 2002, Dasar-Dasar Bimbingan dan Konseling, Jakarta. Rhineka Cipta

Slameto, 1995. Belajar dan faktor-faktor yang Mempengaruhinya, Jakarta : Rineka Cipta

Soetomo. (1993). Dasar-Dasar Interaksi Belajar Mengajar. Cetakan Ke-1. Surabaya: Usaha Nasional.

Suryosubroto. 1997. Proses Belajar Mengajar Di Sekolah. (Jakarta: PT. Rineksa Cipta).

Supardi. 2010. Penelitian Tindakan Kelas. Jakarta: PT Bumi Aksara.

Syaiful Sagala, 2009, Kemampuan Profesional Guru dan Tenaga Kependidikan, Alfabeta, Bandung.

Usman, 2002, Menjadi Guru Profesional, Remaja Rosdakarya, Bandung

Zulhartati, S. (2012).Pembelajaran kooperatif model STAD pada mata pelajaran IPS. Jurnal Guru Membangun, 26(2). 